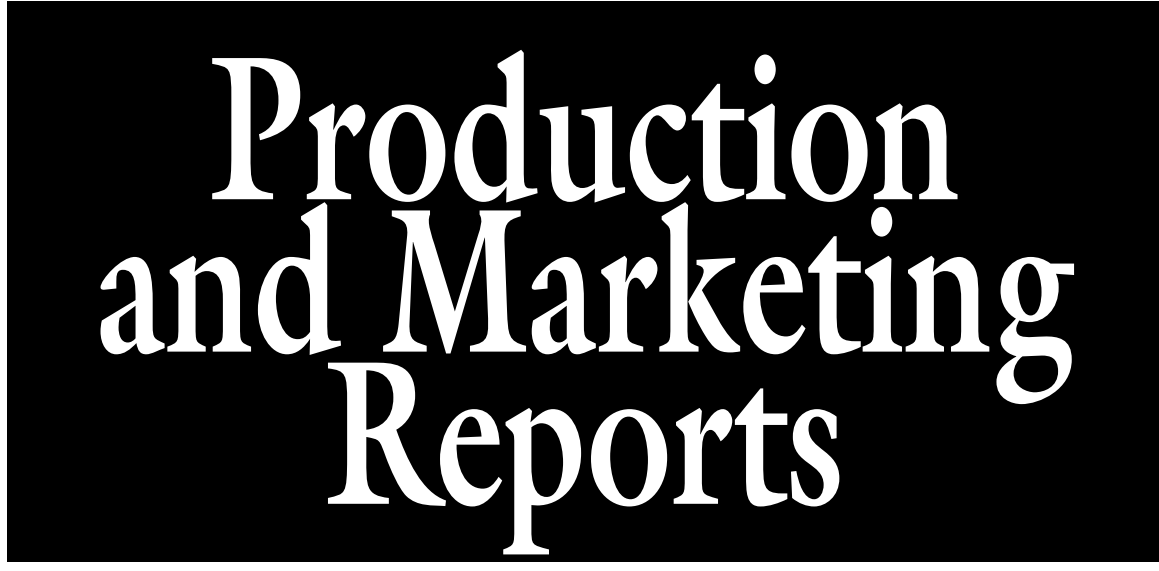

\title{
Producer Preferences for Migrant Labor and the Wage, Hours, and Gross Sales Effects in Alabama's Horticulture Industry
}

\author{
Moriah Bellenger ${ }^{1,5}$, Deacue Fields ${ }^{2,6}$, Kenneth Tilt $^{3}$, \\ and Diane Hite ${ }^{4}$
}

ADDITIONAL INDEX WORDs. H2-A, survey, local labor, probit, log-linear, firm characteristics, part-time workers, industry concerns

SUMMARY. Nursery, greenhouse, and sod production remains very labor-intensive, and a large portion of the agricultural labor force is made up of migrant workers. As a result of the perishable nature of horticultural goods, a skilled and accessible labor supply is imperative for continued industry growth and stability. Using 2004 survey data, this study uses log-linear regression analysis to examine the effects of migrant labor on wages, hours, and gross sales in Alabama's horticulture industry. A binomial probit model is added to measure producer decisions to hire migrant workers. The presence of migrant workers is found to raise average wages within green industry firms but exhibits no significant effects on hours and sales. The binomial probit model indicates that producer concerns may have some influence on their decision to hire migrant workers. Producers who perceive government regulations as a threat to their industry are less likely to hire migrant workers. This indicates that there may be a greater level of government regulation associated with hiring migrant workers when compared with local workers. Concerns for lack of professionalism appear to raise the demand for migrant rather than local workers.

A labama's horticulture industry is both the largest and fastest growing crop sector, comprising almost $40 \%$ of total state crop

${ }^{1}$ Department of Economics, Oregon State University, 303 Ballard Extension Hall, Corvallis, OR 973313612 .

${ }^{2}$ Associate Professor, Department of Agricultural Economics and Rural Sociology, Auburn University, 100B Comer Hall, Auburn, AL 36849-4601

${ }^{3}$ Professor, Department of Horticulture, Auburn University, 139B Funchess Hall, Auburn, AL 36849.

${ }^{4}$ Associate Professor, Department of Agricultural Economics and Rural Sociology, Auburn University, 202 Comer Hall, Auburn, AL 36849-4601

${ }^{5}$ Former graduate researcher in the Department of Agricultural Economics at Auburn University and current graduate teaching assistant in the Department of Economics at Oregon State University.

${ }^{6}$ Corresponding author. E-mail: fieldde@auburn.edu. sales [U.S. Department of Agriculture (USDA), 2005]. Despite recent economic insecurity and the increased competitive pressure of globalization, the continued growth of Alabama's green industry provides a bright spot in the state's economy. Although Alabama's total crops cash receipts declined from \$673.1 million to $\$ 583.8$ million for the period 1980 to 2004 , greenhouse, nursery, and sod sales more than doubled from $\$ 142.7$ million to $\$ 263$ million. Greenhouse, nursery, and sod sales made up more than $36 \%$ of total crop sales in Alabama (USDA, 2005).

Currently, the United States has many questions and concerns regarding the supply of low-skilled manual labor. A large portion of the agricultural labor force is made up of migrant workers; therefore, the immigration reform currently being discussed will have a substantial impact on agricultural labor. Although there has been tremendous growth in mechanization and technological advances in the horticultural industry, nursery, greenhouse, and sod production remains very labor-intensive. As a result of the perishable nature of horticultural goods, a skilled and accessible labor supply is imperative for continued industry growth and stability. The variation in labor composition among producers statewide, from local to migrant, highlights the need to study the use of migrant labor in the horticulture industry. Do migrant workers depress wages as is often feared by local workers? Do firms using migrant labor have higher sales? Are migrant workers likely to work longer hours than their local counterparts? How do producers' attitudes and concerns, regarding labor issues, influence their hiring decisions?

\section{Background}

The United States has a long history of importing agricultural workers to meet seasonal demands for labor. Today, producers' hiring practices are regulated by the Immigration Reform and Control Act of 1986 (IRCA), and agricultural labor is specifically regulated by IRCA section $\mathrm{H} 2$-A, known as the H2-A program. IRCA grants temporary $\mathrm{H} 2-\mathrm{A}$ visas to foreign workers based on two conditions intended to both ensure access to labor for producers and protect local workers from wage decline resulting from labor surplus. To procure $\mathrm{H} 2$-A visas, producers must demonstrate to the U.S. Department of Labor that:

1. There are not sufficient workers who are able, willing, qualified, and available at the time and place needed to perform the labor or services involved in the petition, and

2. The employment of the alien in such labor or services will not adversely affect the wages and working conditions of workers in the U.S. similarly employed.

Despite these provisions, both producers and U.S. workers voiced concerns with the passage of IRCA. Producers feared that the H2-A program would ultimately restrict their 
labor supply, placing upward pressure on wages, whereas U.S. workers feared the opposite, that the H2-A program would lead to a labor surplus, depressing both wages and working conditions (Gunter et al., 1992; Pagan, 1998; Perloff et al., 1998; Thompson and Wiggings, 2002). Concerns of both producers and workers are valid and deserve further investigation.

The present study uses data from a 2004 survey of 2286 Alabama green industry producers to evaluate some impacts of migrant labor in the industry. The specific research objectives are to estimate the effects of migrant labor on wages, hours worked, and gross sales. In addition, stated producer concerns contained within the survey are used to evaluate hiring decisions. Few similar studies addressing labor issues in the green industry can be found in the existing literature. Ise and Perloff (1995) find that documentation among migrant workers significantly influences both wages and hours. Using data from the 2000 National Agricultural Worker's Survey, the authors find that unauthorized workers earn a median income between $\$ 2500$ and $\$ 5000$, and those with amnesty earn between $\$ 5000$ and $\$ 7500$, whereas the median income for other farm workers is between $\$ 7500$ and $\$ 10,000$. In addition, unauthorized workers, as well as those with green cards and native citizens of Latino descent, work more hours than their U.S. counterparts. The current literature lacks an analysis of migrant workers and gross sales as well as an evaluation of producer decisions to hire migrant versus local labor.

\section{Data}

This study evaluates data from a 2004 survey of Alabama green industry firms (nursery and greenhouse, lawn and landscape services, turfgrass and sod). The survey was administered using Dillman's tailored design methodology (Dillman, 2000). Mailing lists were acquired from the Alabama Department of Agriculture and Industries (ADAI) for nursery and greenhouse growers, nursery stock dealers, and licensed lawn and landscape service providers. Membership and mailing lists from the Alabama Nurserymen's Association and Alabama Turfgrass Association were used to verify and update ADAI lists. The instruments were developed and pretested based on other instruments found in relevant literature. Table 1 presents information on mailing and response rates for each sector surveyed. Table 1 shows that response rates ranged from $13.5 \%$ for lawn and landscape services to $27.9 \%$ for turfgrass and sod producers. Blank surveys and surveys with limited information were excluded from the number of completed responses.

The results of the survey are reported based on the 321 completed respondents, and they are expanded to make inferences about the entire population. Expansions performed on these data indicated that the nursery and greenhouse, turfgrass and sod, and the lawn and landscape sectors provide a representative sample of the population of firms in the industry. The total number of respondents represents $14.0 \%$ of the firms participating in green industry activities. Table 2 summarizes a portion of the labor-related survey results. It is interesting to note that, in this survey, the average seasonal part-time wage actually exceeds the average full-time wage.

\section{Methodology}

Five equations are estimated using the log-linear or constant elasticity model. There are two wage equations and two hours-worked equations, both as a function of the percentage of migrant labor, firm characteristics, and local demographics. The wage and hours equations are separated for full-time and seasonal/part-time employees. The final equation estimates gross sales as a function of firm characteristics, percent migrant, and local demographics (Griffiths et al., 1993). A binomial probit model is also added to measure the decision to hire migrant workers based on producer concerns, firm characteristics, and local demographic information. Table 3 provides a description of explanatory variables used in these models.

Although primary data collection offers many advantages, practicality places limitations on the amount and detail of information that can be accessed when compared with larger national samples. Wage and hour information contained within the survey represents average wage and hour levels for each firm rather than individual employee wages and hours. Employees are classified as either full-time (FT) or seasonal/ part-time (SPT), but the survey does not identify which employees are local and which are migrant workers. Instead, producers were asked to estimate the percentage of their total employees that is local and the percentage of their total employees that is migrant workers. Producers were not asked to provide any socioeconomic information for their employees on either individual or aggregate levels. Instead, survey respondents were matched to county-level census data to approximate socioeconomic conditions.

WAGES.

1. $\operatorname{lnSPT}$ Wage $=\beta 1+\beta 2 \ln$ Percent Migrant $+\beta 3 \ln S P T$ Employees + $\beta 4 \ln S P T$ Hours $+\beta 5 \ln$ Total Employees $+\beta 6 \ln$ Total Benefits $+\beta 7 \ln E x-$ pected Volume Change + $\beta 8 \ln$ Percent of Sales to Out of State Customers $+\beta 9 \operatorname{lnEducation}+$ $\beta 10 \ln E m p l o y m e n t \quad$ Level + $\beta 11 \operatorname{lnGross}$ Sales $+\varepsilon$

2. $\operatorname{lnFT}$ Wage $=\lambda 1+\lambda 2 \ln$ Percent Migrant $+\lambda 3 \ln S \mathrm{PT}$ Employees $\lambda 4 \ln \mathrm{FT}$ Employees $+\lambda 5 \ln$ Total

Table 1. Summary of survey mailed and total responses of Alabama firms by green industry sector.

\begin{tabular}{|c|c|c|c|c|c|}
\hline Sector & $\begin{array}{c}\text { Presurvey } \\
\text { postcard (no.) }\end{array}$ & $\begin{array}{c}\text { Surveys } \\
\text { mailed (no.) }\end{array}$ & $\begin{array}{c}\text { Total } \\
\text { responses (no.) }\end{array}$ & $\begin{array}{c}\text { Completed } \\
\text { responses (no.) }\end{array}$ & $\begin{array}{c}\text { Response } \\
\text { rate (\%) }\end{array}$ \\
\hline Nursery and greenhouse & 851 & 822 & 158 & 114 & 13.9 \\
\hline Turfgrass and sod & 64 & 61 & 24 & 17 & 27.9 \\
\hline Total & 2,345 & 2,286 & 425 & 321 & 14.0 \\
\hline
\end{tabular}


Table 2. Mean, SD, range, and number of responses for labor-related variables from the 2004 survey of Alabama green industry firms. ${ }^{\mathrm{z}}$

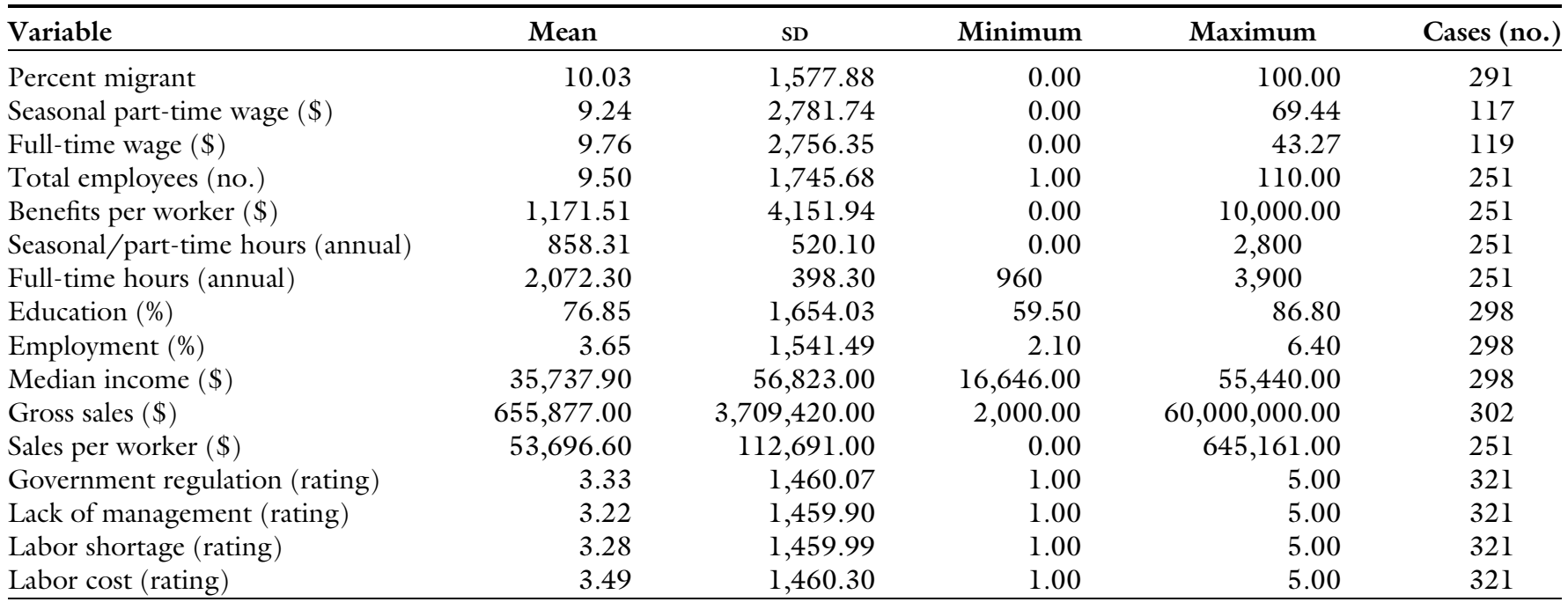

${ }^{\mathrm{z}}$ The education, employment, and median income variables are from county census data.

Employees $+\lambda 6 \ln$ Total Benefits + $\lambda 7$ lnExpected Volume Change + $\lambda 8 \ln$ Percent of Sales to Out of State Customers $+\lambda 9 \ln$ Education + $\lambda 10 \operatorname{lnEmployment} \quad$ Level + $\lambda 11 \operatorname{lnGross}$ Sales $+\varepsilon$

The two wage equations estimate wages as a function of four general characteristics: migrant status, employment composition, firm size, and socioeconomic status. The percentage of total employees that is migrant workers is used to represent the effects of migrant status. The number of seasonal part-time employees, full-time employees, total employees, and total benefits represent both the size and composition of each firm's labor force. Producers were asked to estimate their expected change in volume for the coming year as well as the percentage of their total sales reaching out-of-state customers. These estimations, coupled with 2004 gross sales information, serve as an indicator of firm size. Countylevel census data for high school graduation and employment rates serve as a proxy for local socioeconomic conditions.

Based on the results of similar studies (Hanson et al., 2002; Ise and Perloff, 1995), percent migrant should be inversely related to both seasonal part-time and full-time wages. It is assumed that as firm size increases, increased demand for labor will positively influence seasonal parttime and full-time wage rates. The effects of employee composition are unknown. For instance, as the number of seasonal part-time employees

Table 3. Description of explanatory variables used in log-linear and binomial probit models. ${ }^{\mathrm{z}}$

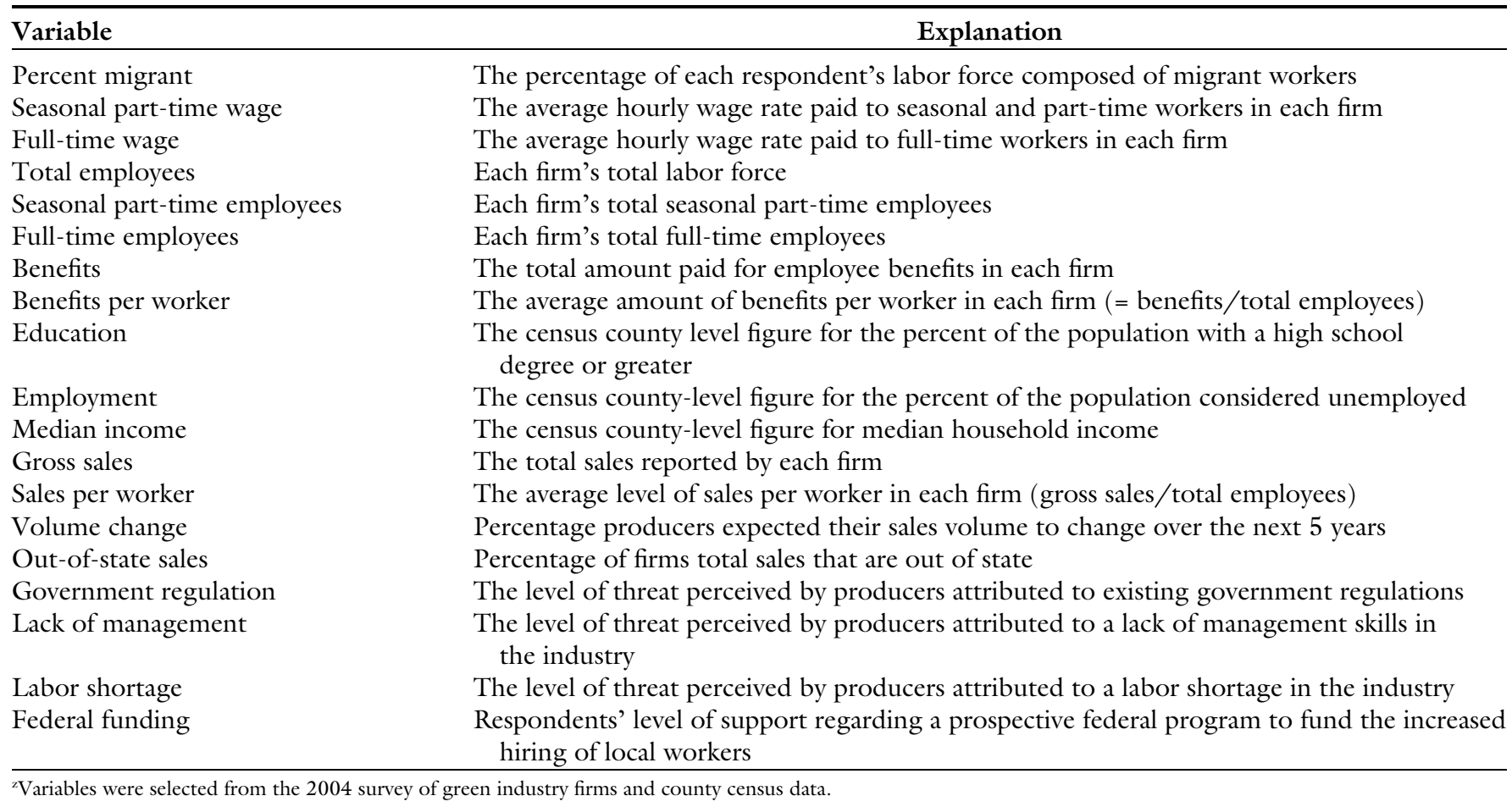


increases, this could signal increased demand for seasonal part-time workers, which would place upward pressure on seasonal part-time wage rates. Similarly, an increase in the number of full-time workers could correspond to higher demand for full-time workers and increased full-time wages. Conversely, lower levels of full-time workers may result from the substitution away from full-time to seasonal part-time labor. Consistent with wage model literature, education should be positively related to wages for both seasonal part-time and full-time workers. However, as a result of the low levels of skill involved in hand harvesting, the effects of education are expected to be minimal. Local employment levels serve as a proxy for local labor supply. As employment levels increase, this should signal a restricted labor supply, which would place upward pressure on wages for both seasonal part-time and full-time workers.

\section{Hours.}

3. $\ln S$ PT Hours $=\alpha 1+\alpha 2 \ln$ Percent Migrant $+\alpha 3 \ln S P T$ Employees + $\alpha 4 \ln S P \mathrm{~T}$ Wage $+\alpha 5 \ln$ Total Employees $+\alpha 6 \ln$ Expected Volume Change $+\alpha 7 \ln$ Percent of Sales to Out of State Customers $+\alpha 8 \ln E d u c a t i o n+$ $\alpha 9 \operatorname{lnEmployment} \quad$ Level + $\alpha 10 \ln$ Gross Sales $+\varepsilon$

4. $\operatorname{lnFT}$ Hours $=\psi g 1+\psi 2 \ln$ Percent Migrant $+\psi 3 \ln S$ PT Employees $+\psi 4 \ln$ FT Employees $+\psi 5 \ln$ FT Wage $+\psi 6 \ln$ Total Employees $+\psi 7 \ln \mathrm{Ex}^{-}$ pected Volume Change $+\psi 8 \ln$ Percent of Sales to Out of State Customers $+\psi 9 \ln E d u c a t i o n+$ $\psi 10 \ln$ Employment Level + $\psi 11 \ln$ Gross Sales $+\varepsilon$

The estimate for total hours worked per employee is calculated based on average hours per week and average weeks per year. This figure represents an average for each employee. The two hours equations estimate hours as a function of migrant status, employment composition, firm size, socioeconomic status, and wages.

Using labor data from the U.S. Department of Labor's (2000) National Agricultural Worker's Survey, Ise and Perloff (1995) find a positive relationship between documented migrant workers and hours worked. A similar relationship is expected in this study. To support increased output, firm size indicators are also expected to be positively related to hours worked by both seasonal part-time and full-time workers. Presumably, higher wage rates serve as an indicator of the incentive producers must offer seasonal part-time and full-time employees to maintain a consistent labor supply. A larger number of seasonal part-time and full-time workers is indicative of firm size and should likely have a positive impact on hours worked. However, presumably fulltime workers require more fringe benefits. It may be more efficient for producers to hire fewer full-time workers and pay them to work longer hours. It is assumed that as education levels increase, hours worked should decrease, because education should be inversely related to the availability of low-skilled labor. As the local employment level rises, producers may have less access to additional workers and may rely on existing workers to put in longer hours.

Gross SALES.

5. $\operatorname{lnGross}$ Sales $=\delta 1+\delta 2 \ln$ Percent Migrant $+\delta 3 \ln S P T+\delta 4 \ln F T+$ $\delta 5 \ln$ Total Employees $+\delta 6 \ln$ Expected Volume Change $+\delta 7 \ln$ Out of State Customers $+\delta 8 \ln E d u c a t i o n+$ $\delta 9 \ln$ Employment Level $+\varepsilon$

The equation for gross sales estimates revenue as a function of migrant status, employment composition, firm size, and socioeconomic conditions. Because it is predicted that migrant workers will work longer hours than local workers, percent migrant is predicted to be positively related to gross sales. The effect of employment composition is uncertain. Firms hiring more seasonal part-time workers may do so because full-time, year-round workers are simply not needed to meet output levels. More seasonal part-time workers may also be hired to meet increased demands on output. Firm size indicators are expected to be positively related to gross sales. It is assumed that firms with more employees will have greater levels of output and therefore higher gross sales. It is uncertain whether socioeconomic conditions will have any effect on gross sales. More educated workers presumably will have higher skill levels and may be more productive. Thus, education is predicted to relate positively to gross sales. Increased local employment levels could restrict access to labor supply, which could weaken firm productivity. Employment is predicted to relate negatively to gross sales.

Migrant Labor.

6. Migrant Labor $=\varphi 1+\varphi 2 \mathrm{Fed}-$ eral Funding $+\varphi 3$ Total Employees + $\varphi 4$ Total Benefits $+\varphi 5$ Expected Volume Change $+\varphi 6$ Education + $\varphi 7$ Employment Level $+\varphi 8$ Gross Sales $+\varphi 9$ Government Regulation + $\varphi$ l0Lack of Professionalism + $\varphi$ l lLack of Management $+\varphi$ 12Labor Shortage $+\varphi 13$ Labor Cost $+\varepsilon$

A unique component of the survey examines producers' attitudes and concerns regarding a variety of labor issues. Producers were asked:

1. To rate their support of a federally funded program to hire local labor rather than migrant labor;

2. To rate the level of threat to the industry posed by government regulation;

3. To rate the level of threat to the industry posed by lack of professionalism;

4. To rate the level of threat to the industry posed by lack of management;

5. To rate the level of threat to the industry posed by labor shortage; and

6. To rate the level of threat to the industry posed by labor cost.

Producers chose 1) strongly disagree, 2) disagree, 3 ) neither agree nor disagree, 4) agree, or 5) strongly agree.

The firm's decision to hire migrant workers is estimated as a function of these producer attitudes joined with previously explained indicators for firm size and local socioeconomic conditions.

Producers who would support a federally funded program to hire local rather than migrant labor likely prefer local labor to migrant labor. It is predicted that producer attitudes regarding possible federal funding of local labor will be negatively related to the hiring of migrant labor. The effect of government regulation is uncertain. Producers may perceive that migrant workers are less subject to regulation than local workers, and migrant workers themselves may be less aware or less demanding of codified working conditions. However, to hire workers through the $\mathrm{H} 2-\mathrm{A}$ program, producers must meet requirements imposed by the Department of Labor and Immigration and 
Naturalization Service. This necessary interaction with government agencies may discourage producers from hiring migrant workers.

Concern for lack of professionalism may prompt producers to hire more local rather than migrant labor. Conversely, lack of professionalism may be the result of increased dependency on migrant labor as opposed to local labor. Lack of management may prevent producers from hiring migrant labor, because migrant workers could require more oversight than required by local workers. However, a lack of management could stem from a disproportionate use of migrant versus local labor.

A labor shortage provides the most explicit justification for hiring migrant rather than local labor. It is predicted that concern for labor shortage will be positively related to percent migrant. Similarly, it is predicted that concern for labor costs will also be positively related to percent migrant. Producers may perceive that migrant workers impose fewer labor costs such as employee benefits than do local workers.

Indicators for firm size should relate positively to percent migrant. In addition to their greater demand for labor, larger firms may be better suited to the H2-A program. The $\mathrm{H} 2$-A application process may exact an inordinate level of resources to be worthwhile for producers seeking only marginal increases in their labor force.

It is unknown if education will have any effect on percent migrant. High levels of education in the local labor market may result in fewer local workers available to green industry producers. Local workers may seek more high-skilled employment. The local employment level should reflect producer concerns regarding labor shortage. As the local employment level rises, labor supply may be restricted, forcing producers to seek migrant workers as a supplement to local labor. It is predicted that the employment level will be positively related to percent migrant.

\section{Results}

Wage estimates for seasonal part-time and full-time workers are listed in Table 4 columns 2 and 3 , respectively. Hours estimates for seasonal part-time and full-time workers are listed in Table 4 columns 4 and 5, respectively. Gross sales estimates are listed in Table 4 column 6. A 0.05 critical value is used to measure significance, and a standard null hypothesis that the coefficient is equal to zero is used for all variables.

In the log-linear model, because both the dependant and independent variables are logged, parameter estimates actually represent elasticity. For instance, the coefficient for migrant is 0.096 , meaning that a $1 \%$ increase in migrant workers corresponds to roughly a $0.10 \%$ increase in seasonal part-time wages.

In the seasonal part-time wages equation, the null hypothesis is rejected for migrant, seasonal parttime employees, seasonal part-time hours, total employees, and out-ofstate sales. There is actually a positive relationship in this model for percent migrant and seasonal part-time wages. As the portion of labor composed of seasonal part-time workers increases, and as the number of hours worked by seasonal part-time workers increases, there is a corresponding increase in seasonal part-time wages. If migrant workers are more desirable to some producers, higher seasonal part-time wages may be offered to attract migrant workers. Total employees, indicative of firm size, is negatively related to seasonal parttime wages. This result differs from a priori expectations; however, this suggests that smaller firms pay higher wages to seasonal part-time workers and larger firms are able to pay lower wages.

Benefits and expected volume change are both positive and significant at the 0.10 level. The results suggest that firms providing greater levels of benefits also provide higher

Table 4. Coefficients of the log-linear model showing the percentage impact on wages, hours worked, and gross sales that results from a $1 \%$ change in each explanatory variable.

\begin{tabular}{|c|c|c|c|c|c|}
\hline Variable & $\begin{array}{c}\text { Seasonal part-time } \\
\text { wages }^{z}\end{array}$ & $\begin{array}{l}\text { Full-time } \\
\text { wages }\end{array}$ & $\begin{array}{c}\text { Seasonal } \\
\text { part-time hours }\end{array}$ & $\begin{array}{c}\text { Full-time } \\
\text { hours }\end{array}$ & Gross sales \\
\hline Constant & $-0.130(-0.229)$ & $-0.707^{*}(-2.632)$ & $1.423 *(1.998)$ & $2.453 *(6.003)$ & $10.559 *(30.834)$ \\
\hline \multicolumn{6}{|l|}{ Seasonal part-time } \\
\hline employees & $0.002 *(8.450)$ & $0.000(-1.796)$ & $-0.001 *(-2.906)$ & $0.000 *(-2.695)$ & $-0.001(-1.455)$ \\
\hline Seasonal part-time hours & $0.383^{*}(9.156)$ & $\mathrm{N} / \mathrm{A}$ & $\mathrm{N} / \mathrm{A}$ & $\mathrm{N} / \mathrm{A}$ & $\mathrm{N} / \mathrm{A}$ \\
\hline Full-time hours & $\mathrm{N} / \mathrm{A}$ & $0.433^{*}(14.921)$ & $\mathrm{N} / \mathrm{A}$ & $\mathrm{N} / \mathrm{A}$ & $\mathrm{N} / \mathrm{A}$ \\
\hline Full-time wages & $\mathrm{N} / \mathrm{A}$ & $\mathrm{N} / \mathrm{A}$ & $\mathrm{N} / \mathrm{A}$ & $0.669 *(6.449)$ & $\mathrm{N} / \mathrm{A}$ \\
\hline Total employees & $-0.329 *(-4.165)$ & $-0.181(-1.512)$ & $0.264^{*}(2.527)$ & $0.141(0.898)$ & $0.686^{*}(3.203)$ \\
\hline Benefits & $0.033(1.850)$ & $0.037^{*}(2.082)$ & $\mathrm{N} / \mathrm{A}$ & $\mathrm{N} / \mathrm{A}$ & $\mathrm{N} / \mathrm{A}$ \\
\hline Volume change & $0.001(1.910)$ & $0.001(0.764)$ & $0.000(0.058)$ & $-0.001(-1.682)$ & $0.000(-1.676)$ \\
\hline $\mathrm{R}^{2}$ & 0.268 & 0.345 & 0.219 & 0.274 & 0.170 \\
\hline
\end{tabular}

${ }^{\mathrm{z}} t$ ratio is in parentheses.

${ }^{*}$ Coefficient estimates are significant at $P \leq 0.05$.

$\mathrm{N} / \mathrm{A}=$ not applicable. 
wages rather than substitute benefits for wages. These firms may simply choose to offer higher levels of compensation than other firms for seasonal part-time labor. Expected volume change could signal a rise in demand for seasonal part-time labor, which would result in higher wages.

In the full-time wages equation, the null hypothesis is rejected for percent migrant, full-time hours, benefits, education, and employment. Again, the hiring of migrant workers is positively related to wages. A $1 \%$ increase in the number of migrant workers raises wages by roughly $0.09 \%$. There appears to be no substitution effect on full-time wages by employing more seasonal part-time employees, although it is only significant at the 0.10 level. Full-time hours worked is positive and highly significant for full-time wages. The model estimates that a $1 \%$ increase in hours worked raises full-time wages by $0.43 \%$. Benefits are also again positively related to wages. The demographic indicators are significant for full-time wages. Consistent with the wage literature, education is positively related to wages in this model. A $1 \%$ increase in the local high school graduation rates corresponds to a $1.21 \%$ raise in full-time wages. Interestingly, the local employment rate is negatively related to full-time wages. A labor shortage should increase rather than decrease wages. On the other hand, the employment rate is for all industries rather than simply the green industry. There may actually be a surplus of available labor for the green industry in these areas.

The null hypothesis can be rejected for seasonal part-time employees, seasonal part-time wage, and total employees in the seasonal parttime hours equation. Percent migrant has no effect on seasonal part-time hours in the model. As predicted, seasonal part-time wage is positively related to hours worked by seasonal part-time employees. A 1\% increase in the seasonal part-time wage rate corresponds to a $0.51 \%$ in the number on hours worked for seasonal part-time labor. Although the number of total employees is positively related to seasonal part-time hours, the number of seasonal part-time employees is inversely related to seasonal part-time hours. Neither the producer expectations nor the socioeconomic indicators is significant.

In the full-time hours equation, the null hypothesis can be rejected for seasonal part-time employees, fulltime wages, expected volume change, education, and employment. As predicted, full-time wages are positively related to full-time hours worked. A $1 \%$ increase in the full-time wage rate raises full-time hours by $0.66 \%$. Contrary to expectations, expected volume change is slightly negatively related to full-time hours at the 0.10 level. Although the number of seasonal part-time employees is significant, its effect is virtually zero. Again, the socioeconomic indicators are significant for full-time employees. As predicted, the local education level is inversely related to hours worked, whereas the local employment level is positively related to full-time hours.

The null hypothesis can only be rejected for full-time employees and total employees in the gross sales equation. Firms hiring more full-time employees have higher gross sales at the means. A $1 \%$ increase in the number of full-time employees raises gross sales by $0.62 \%$. The coefficient for total employees is positive as predicted. A $1 \%$ increase in the number of total employees raises gross sales by $0.69 \%$. In contrast, the other indicators for firm size are both negative, although not significant. Percent migrant is positive as expected, but also not significant. Neither of the socioeconomic indicators is significant. It should be noted that although total employees is positive, the number of seasonal part-time employees is not significant. It is difficult to interpret this inconsistency. Total employees includes other types of workers such as management and sales staff. It is more indicative of firm size than employee composition. So, although it is clear that additional employees are related to higher sales, it is unclear which types of employees are driving that relationship.

A binomial probit model is added to measure the propensity to hire migrant workers given individual firm characteristics, stated producer concerns, and local demographic information. The results of this model listed in Table 5 show only two variables that have a significant influence on the producer's propensity to hire migrant labor.

The marginal effects can be interpreted as a change in the probability of hiring migrant workers as a

Table 5. Binomial probit model estimating the propensity to hire migrant labor given firm characteristics. ${ }^{\mathrm{z}}$

\begin{tabular}{|c|c|c|c|c|c|}
\hline Variable & Coefficient & $\begin{array}{c}\text { Marginal } \\
\text { effects }\end{array}$ & $\mathrm{SE}^{\mathrm{y}}$ & Mean & $P$ \\
\hline Constant* & -2.225 & 0.000 & $0.572(-3.888)$ & 1.000 & 0.000 \\
\hline Federal funding & 0.051 & -0.052 & $0.072(0.709)$ & 2.456 & 0.478 \\
\hline $\begin{array}{l}\text { Seasonal part-time } \\
\text { employees }\end{array}$ & 0.043 & -0.044 & $0.033(1.328)$ & 2.605 & 0.184 \\
\hline Full-time employees & 0.035 & -0.036 & $0.036(0.949)$ & 3.528 & 0.343 \\
\hline Total employees & -0.001 & 0.001 & $0.029(-0.029)$ & 7.656 & 0.977 \\
\hline Benefits & 0.000 & 0.000 & $0.000(-1.512)$ & $13,886.50$ & 0.131 \\
\hline Volume change & 0.001 & -0.001 & $0.001(1.622)$ & 46.409 & 0.105 \\
\hline Education & 0.026 & -0.026 & $0.017(1.571)$ & 72.252 & 0.116 \\
\hline Employment & -0.027 & 0.027 & $0.022(-1.229)$ & 57.540 & 0.219 \\
\hline Gross sales & 0.000 & 0.000 & $0.000(1.368)$ & $62,287,683$ & 0.171 \\
\hline $\begin{array}{l}\text { Government } \\
\text { regulation* }\end{array}$ & 0.226 & -0.229 & $0.099(2.283)$ & 3.252 & 0.022 \\
\hline $\begin{array}{l}\text { Lack of } \\
\text { professionalism* }\end{array}$ & -0.264 & 0.268 & $0.105(-2.513)$ & 3.418 & 0.012 \\
\hline Lack of management & 0.066 & -0.067 & $0.106(0.626)$ & 3.135 & 0.531 \\
\hline Labor shortage & 0.154 & -0.156 & $0.093(1.665)$ & 3.233 & 0.096 \\
\hline Labor cost & -0.015 & 0.015 & $0.110(-0.132)$ & 3.443 & 0.895 \\
\hline $\begin{array}{l}\chi^{2} \\
P\left(\chi^{2}\right)\end{array}$ & $\begin{array}{r}58.729 \\
0.000\end{array}$ & & & & \\
\hline
\end{tabular}

${ }^{\mathrm{z}}$ Marginal effects show the change in the probability of hiring migrant workers resulting from the explanatory variables.

${ }^{y} t$ values are in parentheses.

${ }^{*}$ Coefficient estimates are significant at the 0.05 level. 
result of the explanatory variables (Greene, 1995). For instance, the marginal effect for government regulation is equal to -0.23 . This means that increased government regulation reduces the probability of hiring migrant workers by roughly $23 \%$. The marginal effect for lack of professionalism, 0.27 , can be interpreted analogously as a $27 \%$ increase in the probability of hiring migrant workers. The $\chi^{2}$ of 58.73 indicates the model is significant at the 0.01 level.

Government regulations and lack of professionalism are significant at the 0.05 level, whereas labor shortage is significant at the 0.10 level. The model estimates a negative relationship between respondents who perceived a high level of government regulation as a threat and the decision to hire migrant workers. This indicates when producers view higher levels of government regulation as a threat, they are deterred from hiring migrant workers. Producers may associate greater levels of government regulations for migrant workers. There is a positive relationship between a concern for lack of professionalism and the hiring of migrant workers. Producers may feel that local workers exhibit lower levels of professionalism than their migrant counterparts. Migrant workers may often be perceived to be more committed and hard-working than local workers in agriculture. It is interesting that concerns for labor shortage are negatively related to the hiring of migrant workers. This may be the result of a lack of awareness and information regarding the $\mathrm{H} 2$-A program or a lack of access to H2-A workers.

\section{Conclusion}

Migrant labor issues are a major concern facing agriculture and especially the horticultural industry in the United States. Labor issues continue to be at the forefront of many congressional debates. Contrary to fears expressed by local workers, in this study, the presence of migrant workers appears to raise wage levels for both seasonal part-time and full-time workers. The total number of hours worked by seasonal part-time and full-time employees is also positively related to wage rates. This may be a result of the adverse effect wage rate set by the U.S. Department of Labor. This rate represents the minimum that must be paid to United States and foreign workers by employers of nonimmigrant, foreign agriculture workers. In 2006, the adverse effects wage rate for Alabama was \$8.37. However, in this study, migrant labor has no significant effect on the total number of hours worked by either seasonal part-time or fulltime employees. Local demographics, measured by education and employment levels, have significant effects for full-time wages and hours, but have no significant effects for seasonal part-time wages and hours in this study. Consistent with the labor literature, education levels are positively related to wages and inversely related to hours worked for full-time employees. Local employment levels are positively related to total hours worked and inversely related to wages. The lack of significance of gross sales, outof-state sales, and volume change variables suggest that there is no major difference in average wages paid or hours worked between firms of different sizes.

This study finds that producer concerns may have some influence on their decision to hire migrant workers. Producers who perceive government regulations as a threat to their industry are less likely to hire migrant workers. This indicates that there may be a greater level of government regulation associated with hiring migrant workers when compared with local workers. Concerns for lack of professionalism appear to raise the demand for migrant rather than local workers. Producers may credit migrant workers with a stronger work ethic than local labor. A larger data set comprised of individual-level responses, rather than average and aggregate levels, could strengthen the probit model estimates.

A survey of individual employees, containing both demographic and wage/hours information, could reveal more significant relationships among migrant status, socioeconomic indicators, and wages/hours. In this study, data for migrant status and wages/hours were derived from average levels reported by producers. Information for individual workers could render greater differentials in wages/hours between migrant and local workers. Socioeconomic indicators in this study were weakly proxied using county-level census data. Individual education and experience levels may be significantly related to wages/ hours for seasonal part-time employees, even if local education levels are not significant.

\section{Literature cited}

Dillman, D.A. 2000. Mail and internet surveys: The tailored design method. Wiley, New York.

Greene, W.H. 1995. LIMDEP version 7.0. Econometric Software, New York.

Griffiths, W., R.C. Hill, and G.G. Judge. 1993. Learning and practicing econometrics. Wiley, New York.

Gunter, L.F., J.C. Jarrett, and J.A. Duffield. 1992. Effect of U.S. immigration reform on labor-intensive commodities. Amer. J. Agr. Econ. 74:897-906.

Hanson, G.H., R. Robertson, and A. Spilimbergo. 2002. Does border enforcement protect U.S. workers from illegal immigration? Rev. Econ. Stat. 84:73-92.

Ise, S. and J. Perloff. 1995. Legal status and earnings of agricultural workers. Amer. J. Agr. Econ. 77:375-386.

Pagan, J.A. 1998. Employer sanctions on hiring illegal labor: An experimental analysis of firm compliance. J. Econ. Behav. Organ. 34:87-100.

Perloff, J.M., L. Lynch, and S. Gabbard. 1998. Migration of seasonal agricultural workers. Amer. J. Agr. Econ. 80:154-164.

Thompson, C.D. and M.F. Wiggings. 2002. The human cost of food: Farmworkers' lives, labor, and advocacy. University of Texas Press, Austin.

U.S. Department of Agriculture. 2005. Alabama agricultural statistics 2005. 3 Oct. 2007. <http://www.nass.usda.gov/ Statistics_by_State/Alabama/Publications/ Annual_Statistical_Bulletin/2005/ pg04.htm>.

U.S. Department of Labor. 2000. Findings from the national agricultural workers survey 1997-1998-A demographic and employment profile of United States farm workers. U.S. Dept. Labor Res. Rpt. No. 8. 